\title{
Social Work Penalty as the Alternative of Imprisonment
}

\author{
Kuat Puji Prayitno ${ }^{1 *}$, Dwi Hapsari Retnaningrum ${ }^{2}$ and Rani Hendriana ${ }^{3}$ \\ ${ }^{1}$ Departement of Criminal Law, Faculty of Law, Jenderal Soedirman University, Indonesia \\ ${ }^{2}$ Departement of Criminal Law, Faculty of Law, Jenderal Soedirman University, Indonesia \\ ${ }^{3}$ Departement of Criminal Law, Faculty of Law, Jenderal Soedirman University, Indonesia
}

\begin{abstract}
Social work penalty is a new type of penalty listed in the draft of KUHP. The purpose of te imposition of social work penalty for the perpetrators is to cause embarrassment for committing such crimes so that to establish a deterrent effect. The imposition of this sanction will reduce the stigmatization of imprisonment, so it is necessary to understand what the background and how the prospect as an alternative to imprisonment is. The method used to solved the problem is the normative juridical method, as well as the aim to be achieved are to contribute ideas to the development of criminal law. Social work penalty is not applied to all criminal acts which are punishable by imprisonment. In addition, the judges are also required to consider several matters, one of which is the defendant's acknowledgement of a crime committed so that the perpetrators realized their mistake(s). If the judge are not careful on applying this punishment, then it is feared that there will he disparities which will harm the perpetrators. It is hoped that with the enactment of the new KUHP, social work penalty can be carried out according to its objectives.
\end{abstract}

\section{Introduction and Literature Review}

Social work penalty is a new type of penalty listed in the draft of KUHP, which did not exist before in the KUHP. The background to the existence of social work penalty, one of which is based on consideration to reduce the adverse effects of imprisonment. By Bambang Poernomo stated:

"Prison crimes that deprive human freedom deserve attention. On the one hand there is a high percentage of court judge decisions that impose imprisonment on the defendant, on the other hand in its implementation it concerns the human dignity of the prisoner and his position as a citizen or resident of the Republic of Indonesia" [1].

Crucially, to the detrimental effect of imprisonment not only on the ineffectiveness of criminal sanctions, but also on the facilities and infrastructure within the Penal Institution which does not allow all prisoners to get the skills expected. Centre for Detention Studies (CDS) research results show that problems overcrowded cannot yet be resolved, even though they have negative effects that are not simple, including increasing rates of rape and sexual violence, limited resources available to each occupant, and limited resources related to education and job training that have the opportunity to increase the occurrence of crime after detention / imprisonment [2].

Gresham M. Sykes explained the meaning of suffering during his imprisonment as deprivation of liberty, the seizure of property, the seizure of rights to be able to have sexual relations, seizure of autonomy, seizure of security [1]. the suffering of prisoners has not yet been completed even though they have been released from prison because they still face stigma, labels, or labels from the community. Rob White and Fiona Haines, stated:

A labelling approach to the definition of crime argues that crime only really exists when there has been a social response to particular activity which labels that activity as criminal. If there is no label, there is in effect no crime [3].

In order to overcome the adverse effects of imprisonment, it is necessary to look for alternatives to short-term prison sentences. One of them is social work penalty.

\footnotetext{
${ }^{*}$ Corresponding author: kuatunsoed@gmail.com
} 


\section{Objective of the Study}

The focus of the research is to find out the reasons why social work penalty is included as one kind of penalties and how its prospect in the future

\section{Methodology}

The method that is being used is normative / doctrinal juridical, with descriptive specification. The data that is being used is secondary data by means of library research. Approach method with historical and conceptual approach. The collected data is analysed qualitatively. Analysis with a qualitative approach makes the quality of the data is vital. By deducting conclusions. According to Soetandyo Wigjosoebroto, in doctrinal legal research, formal logic with deductive syllogism is commonly used [4]. Deduction reasoning is a process of reasoning that departs from the angle of the general statement to arrive at a conclusion that will answer the question [5].

\section{Discussion}

\subsection{Background of the Social Work Penalty as a Penalty}

Why social work penalty appear as one of the fundamental penalty in the KUHP is inseparable from criticism of criminal law, especially in the imposition of criminal sanctions (imprisonment). The overcapacity of prison inmates is one of the benchmarks for the number of judges imposing imprisonment. Marcus Priyo Gunarto stated:

"In terms of law enforcement, overcapacity also occurs because the perception of law enforcers sees criminal sanctions for deprivation of independence as more effective than sanctions for acts or other types of crimes that are not deprivation of liberty [6].

The development of criminal law cannot be separated from the development of human civilization. Even said criminal law is an indicator or indicator of a nation's life.

According to Montesquieu, any punishment that is not born of absolute necessity is despotic [7]. In the criminal law literature according to the pure normative nature of the mind, the discussion of the criminal will always collide at a paradoxal point of conflict, namely that criminal acts on the one hand are held to protect one's interests, but on the other hand it turns out to rape the interests of someone else by giving punishment in the form of suffering to someone [1].

By Rupert Cross and Philip Asterley Jones, crime is defined as a legal wrong remedy for which is the punishment of offender at the instance of the State. Legal wrongs may be civil or criminal, and this distinction depends on that between civil and criminal law. The civil law is primarily concerned with the rights and duties of individuals inter se, whereas the criminal law defines the duties which a person owes to society [8]. Although it has a bad impact, but the view or the nature of the mind to abolish the criminal and criminal law, according to Roeslan Saleh is wrong.

Presented by Roeslan Saleh;

So, if on the one hand criminal law and criminal justice are said to be still useful, while on the other hand the criminal law cannot be abolished or abolished, or we get out of trouble, then nothing else can be done but still stick to the law which contains wavering doubts. Therefore we must be restrained and careful in their use. Criminal law is used only if it is inevitable [9].

The imposition of criminal sanctions cannot be separated from criminal purpose theory. The First Theory is absolute theory [10]. This theory aims to satisfy those who hold grudges both from the people themselves who are harmed or become victims. This theory is primitive. According to Helbert L. Packer there are two versions of absolute theory, namely revenge theory and expiation theory. Revenge means that the criminal is paid back; expiation means that he pays back. The revenge theory treats all crimes as if they were certain crimes of physical violence. The exposition theory treats all crimes as if they were financial transactions [11].

Second, relative theory. The basis for justifying the existence of a criminal according to this theory lies in its purpose. Criminal punishment is not because people make crime but so that people do not commit crime [10]. Regarding the criminal purpose for ordinary crime prevention, it is distinguished between the terms special and general prevention or often also used the terms "special deterrence" and "general deterrence". With special prevention is intended the criminal influence on the convicted person. So the prevention of crime is to be achieved by the criminal by influencing the behavior of the convicted person not to commit another crime. By general prevention is intended to be a criminal influence on society in general. This means that the prevention of crime is to be achieved by the criminal by influencing the behaviour of members of society in general to not commit 
criminal acts [10]. From the background of criminal law thinking cannot be abolished because there is a goal of punishment, social work penalty is a way that can be done to achieve that goal.

\subsection{The Prospect of Social Work Penalty as the Short-Term Alternative of Imprisonment}

Social work penalty have been implemented in various countries. The results of a study comparing social work penalty in the Netherlands, Poland, and France, there are similarities in the three countries namely placing social work penalty as a fundamental crime. (13). In the RUU KUHP in 2018 the provisions concerning social work penalty are contained in Article 18. The contents of Article 18 principally stipulate that social work penalty is imposed if the defendant will be sentenced to imprisonment of less than 6 months or a fine of the 1st category. From the provisions of this research it can be seen that social work penalty is imposed for minor crimes.

Consideration to impose social work penalty is related to the defendant's recognition of the crime committed, the age of the defendant is appropriate to do work, social history, protection of the defendant's work safety, and the implementation should not be commercialized.

of the several provisions regarding the consideration of criminal imposition of social work, judging from the philosophy of punishment, it is in accordance with the theory of modern punishment which is not merely in the form of a prison, but contains rehabilitation of the perpetrator.

By minimizing the adverse effects of imprisonment, especially short-term imprisonment, the stigma / label / label of the prisoner in the expression once the person is not confident, can be abolished.

One of the main problems in fostering prisoners is that after leaving prison, the community did not accept it, making it difficult for prisoners to live together again to the community.

\section{Conclusion}

Social work penalty as an alternative penalty to imprisonment in the background by the idea of eliminating the adverse effects of imprisonment on prisoners, reducing the capacity of prison inmates, and achieving criminal objectives. The prospects of social work penalty in the future will greatly support the implementation of a more humane criminal law improvement so that it needs to be implemented. In order that social work penalty is not misused, commitment and integrity from law enforcement officials is needed in its implementation.

\section{References}

1. B. Pornomo, Pelaksanaan Pidana Penjara Dengan Sistem Pemasyarakatan (Liberty, Yogyakarta, 1986)

2. CDS , Realitas Penjara Indonesia (Jakarta, 2015)

3. R. White, F. Haines, Crime and Criminology (Oxford University Press, Oxford, 1996)

4. S. Wignjosoebroto, Keragaman dalam konsep umum, Tipe Kajian, dan Metode Penelitiannya, (Refika Aditama, Bandung, 2008)

5. S. Wignjosoebroto, Hukum, Konsep, dan Metode (Setara Press, Malang, 2013)

6. M. P. Gunarto, Restrukturisasi peradilan pidana sebagai upaya mencegah kelebihan kapasitas narapidana di Lembaga Pemasyarakatan, Professor Inauguration Speech Faculty of Law Universitas Gadjah Mada, Yogyakarta (2013)

7. C. Beccaria (Translated by Wahmuji), Perihal Kejahatan dan Hukuman (Genta Publishing, Yogyakarta, 2011)

8. R. Cross, P. A. Jones, An Introduction to Criminal Law (Butterworths, London, 1968)

9. R. Saleh, Segi Lain Hukum Pidana (Ghalia Indonesia, Jakarta, 1984)

10.M. Ali, Dasar-dasar Hukum Pidana (Sinar Grafika, Jakarta, 2011)

11.H. L. Packer, The Limits of Criminal Sanction (Stanford University Press, California, 1994) 